\title{
PUBLIC GOVERNANCE CAPACITY IN THE ACCOUNTABILITY OF VILLAGE-OWNED ENTERPRISE MANAGEMENT IN INDONESIA
}

\author{
Denok Kurniasih', Paulus Israwan Setyoko ${ }^{2}$ \\ 1,2 Department of Public Adminstration Science, Faculty of Social and Political Sciences, \\ Universitas Jenderal Soedirman, Purwokerto. \\ denokkurniasih@yahoo.com
}

\begin{abstract}
The Indonesian Government has encouraged the development of village-owned business as an alternative utilization of village transfer fund. The trust of the Indonesian government in the village government has been seen from the transfer of funds given to the village. This fund aims to develop their village. Building village-owned business should certainly be counterbalanced with a public accountability mechanism. This research aims at describing the capacity of public governance in the accountability system performed by public sector organization. This research also explores public capacity in supporting the accountability of BUMDes management from a cultural perspective. Village communities have distinct characteristics where not all systems can operate without local wisdom. This research employs both quantitative and qualitative approaches and use questionnaire and interview guide as its instruments. This research is conducted in Banyumas and takes 41 village business units and informants consisting of village business manager, village official and villager elements as the samples. The data and information are analyzed using quantitative descriptive analysis method with support of information analyzed using interactive analysis method. The opportunity of stakeholders's involvement in public accountability system is not yet created by public organization. This is due to the strong patrenalistic culture among Indonesian society. The village community tends to give full trust and to the village government, especially the village head. This kind of patrenalistic culture opens opportunities for not optimal accountability horizontally. Consequently, the accountability only applies vertically. This research suggests improving the capacity of public governance in the accountability system of village-owned business management through optimizing stakeholders' role in the accountability of Village-Owned Enterprise's management.
\end{abstract}

Keywords: Accountability, public governance capacity, Village-Owned Enterprise.

\section{Introduction}

Optimism for village's capability of managing village administration continuously emerges in Indonesia. The Indonesian Government's policy support is also continuously given in effort to develop rural area. The Government's belief in and attention to village also increases quite high. The government's belief in village government is shown through the big fund transfer given to village to develop their area. The grant of village fund is the form of the government's belief in village. The great potential of village resources becomes the confirming factor that village will have the capability to manage their administration independently. Villagers even have big contribution to the government as one element to contribute to state tax. Therefore, it is reasonable that the Indonesian Government decides to provide big fund to develop rural area. This commitment may be shown with the development of village fund grant in Indonesia.

Table 1: Village Fund Development in Indonesia

\begin{tabular}{c|c|c|c}
\multicolumn{4}{c|}{ (in trillion) } \\
\hline \multirow{3}{*}{ Year } & \multicolumn{2}{|c|}{ Dana Transfer } & \multirow{2}{*}{ Amount } \\
\cline { 2 - 3 } & $\begin{array}{c}\text { To Village } \\
\text { (Village Fund) }\end{array}$ & $\begin{array}{c}\text { To Region } \\
\text { (DAU) }\end{array}$ & \\
\hline 2015 & 20.8 & 602.4 & 623.2 \\
2016 & 47.0 & 663.0 & 710.0 \\
2017 & 60.0 & 695.9 & 755.9 \\
2018 & 60.0 & 706.2 & 766.2 \\
\hline Source: Ministry of Finance of the Republic of
\end{tabular}

It is fact that, initially, much of village fund is allocated to physical necessities. In 
line with the development of Indonesian villages' creativity, village fund starts to be utilized to build village business unit. Local government also plays active role in encouraging the development of village business by facilitating the establishment of village business and providing various training and brainstorming programs with various parties. The Indonesian Government has issued Law Number 6 of 2014 on Villages and also Regulation of Minister of Village, Less-Developed Village Development and Transmigration of the Republic of Indonesia Number 4 of 2015 on the Establishment, Application and Management, and Dissolution of VillageOwned Enterprise (BUMDes). The regulations greatly support village government to develop their business. This may be viewed with the development of the number of village businesses in Indonesia. There are only 30,000 units of BUMDes in May 2018, and increases to 9,000 units in less than a year, thus there are totally 39,000 units of BUMDes in 2018. This number is claimed to have exceeded the Indonesian Government's target of 5,000 units of BUMDes in five year. However, out of the total number of 74,958 villages in Indonesia, not all of them have BUMDes.

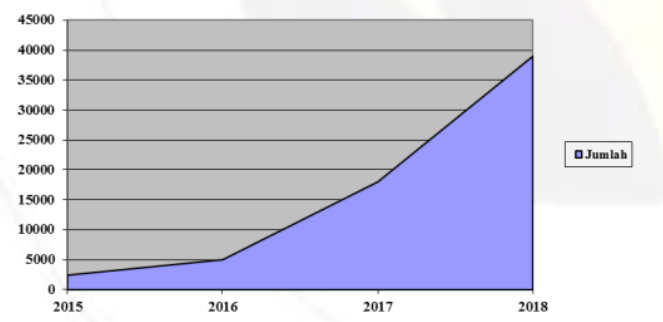

Figure 1. Development of Village Business in Indonesia

Figure 1 shows that village business in Indonesia has developed significantly. Village government is able to respond the central government's stimulus to run village business as an alternative utilization of village transfer fund. However, not all village businesses in Indonesia have run well. The development of BUMDes in Banyumas Regency may be shown with the formation of 126 units of BUMDes covering: 99 units of basic status, 25 units of growing status, and 2 units of developing status, while there is no unit of village business of developed status. These data show that managing village business is not something easy. The area characteristics and the capacity of human resource a village has are certainly a tough challenge for village to run their business.

Operating village business means managing state finance. In managing the finance, village government must pay attention to two important dimensions: first, relation with the central government and, second, relation with the people (Warner, 2010). Relation with the central government is related to accountability, while relation with the people means maintaining trust. This trust is the main issue in public finance which must be continuously maintained by local government, in this case, village government. Current tough challenge in maintaining public finance is indeed related to the effort to improve public trust (Hwang, Jensen, Hult, Roberts, \& Dull, 2013; Murphy \& Skillen, 2018). Such challenge is also faced by village, which is currently authorized to manage a large amount of village fund, one of which is utilized to develop village business, which in Indonesia is known as Village-Owned Enterprise (BUMDes).

Managing village potential through Village-Owned Enterprise has been many implemented in Indonesia, for example, in Banyumas Regency. So far, there are 126 Village-Owned Enterprise distributed in many villages in Banyumas Regency (Report of the Government of Banyumas Regency 2018). BUMDes's growth is 41 percent of the number of villages, showing that village government's response to village business development is very good. However, managing BUMDes accountably as an effort to develop productive economy is in fact still something difficult to be conducted by village government. The main problem faced by village is village's non-strong accountability mechanism, so that BUMDes management is perceived to be less transparent. The first phase research results explain that BUMDes management does not have appropriate accountability mechanism. This can be understood that there is no people involvement in decision making and transparency mechanism through reporting, as well as non-optimal utilization of media for horizontal accountability to the people. The current condition of BUMDes 
management accountability shows that village head is still the center of accountability, while the other stakeholders have not been given with optimal space.

With the phenomenon of low level of public accountability and big potential of BUMDes establishment, appropriate model of public accountability needs to be developed. The accountability mechanism which is conducted so far is still limited to vertical accountability, while horizontal accountability is still weak. Vertical and horizontal accountability failure even takes place in village fund management cases which are experienced by most of villages (Setyoko, 2011). This is due to the strong patrenalistic culture among village community tends to give full trust and to the village government, especially the village head (Leroux, 2015). This kind of patrenalistic culture opens opportunities for not optimal accountability horizontally.

This research results in practical suggestion that BUMDes management accountability system should optimize public governance capacity more. The development of vertical and horizontal accountability system highly requires public governance capacity as explained in the research results. Future BUMDes management accountability model should accommodate the involvement of concerned stakeholders in BUMDes management.

The orientation of public administration starts to shift from merely covering social issue to organization aiming at profit. Currently, public service providing organizations in Indonesia have started to adopt mixed model of profit and non-profit organization. Changes in various rules and in public demand eventually bring up the characteristics of hybrid model which combine profit organization and non-profit organization models (Smith, 2010). It is expected, naturally, that the review of this issue to keep being based on the idea of how to manage public interest efficiently, effectively, accountably and with social justice.

This research aims at studying the problem of weak public accountability in Village-Owned Enterprise (BUMDes) management through public governance perspective. The concept of public governance is a development of the stakeholder theory which may be defined as a model of stakeholders' interaction in order to influence the impacts of a policy (Löffler et al., 2012). The development of public governance concept may develop to be quite contextual and specific, considering that many experts use this concept to discuss various phenomena. Consequently, public governance cannot be separated from the concept of institution, organization, and administrative function in a country, and cannot be separated from the development of people's history and tradition (Wang \& Yang, 2010; Xia, 2011). The difference of stakeholders and the state may result in different definition of public governance (Löffler et al., 2012). In the context of Village-Owned Enterprise (BUMDes) management, the public governance concept may be defined as a stakeholders' involvement based organization management process.

Public governance in public accountability system becomes the ground of democratization implementation of BUMDes management. Village head's dominance in BUMDes management may be minimized with stakeholders' effective involvement, as the realization of public accountability system operation. BUMDes management should put forward public accountability aspect since it involves public fund utilization. Public accountability is a mechanism given to public officials to explain and ensure that they have taken correct action, behaved ethically, and been responsible for their performance (Dubnick, 2017; Geurtsen, Sprenger, \& Schoormans, 2010; Valentinov, 2011).

Previous researches have shown different accountability achievements in rural and urban contexts. Accountability in the form of report as the form of information disclosure is taken important by the people in urban context, while rural people tend to fully entrust to village apparatuses (Hudaya, Smark, Watts, \& Silaen, 2015). Public governance approach for BUMDes management accountability system may mediate vertical and horizontal accountability implementation. In this case, public governance capacity is the capacity of BUMDes stakeholders in relation to their involvement in realization of effective public accountability. Public governance capacity 
has very important role in improving BUMDes management accountability. In the context of this research, public governance capacity may be shown with the degree of involvement of local government, village government, village institution, private sector, and villagers in the BUMDes management accountability system.

\section{Method}

This research is the continuation of previous research which results in data and information of identification of public accountability issues. In this second year, this research results in data and information of the importance of public governance capacity as a model in BUMDes management accountability. This research is conducted by combining quantitative and qualitative approaches in convergent manner (Creswell, 2013). A survey method is employed at the initial phase and the results are analyzed descriptively, qualitatively. The population of this research is all of 126 units of BUMDes distributed in 301 villages in Banyumas Regency. 41 units of BUMDes or $32 \%$ of the population are selected as the sample with a Quota Sampling technique. The data are collected using questionnaire directly given to BUMDes managers. The information is also obtained from private sectors, regional government, village government, and villagers in order to support the descriptively statistical results. The interview and observation data are then analyzed interactively.

\section{Results and Discussion}

Public administration may be defined as public management, governance, or public governance. The reason of these developments of public administration definition is, inter alia, the more difficult definition of public characteristics in public administration (Petrovsky, James, \& Boyne, 2015; Ringeling, 2015). Business matters which are initially deemed taboo to be performed in public sector become the spirit in current public organization management. The emergence of New Public Management (NPM) paradigm strengthens the view, attempting to introduce the spirit of private organization into public organization. Introducing the spirit of private sector business model to public sector is the fastest way to improve the work effectiveness and efficiency of public organization (Benijts, 2014).

Village government is also expected to be able to run business for the purpose of improving people's prosperity. Running village business is indeed a tough challenge for village government. Moreover, the quality of resources a village has are generally low. Therefore, village business has distinctive characteristics compared to other general businesses. Village-owned enterprise is always related to unique geographic, economic and political conditions (Chen, Woods, \& Singh, 2013; Eversole, Barraket, $\&$ Luke, 2014). To maintain the sustainability of village-owned enterprise, the ownership, priority of organization development, and technology need to be diversified. Village business should be oriented to agro-industry, strengthening of quality and brand, business expansion and encouraging regional economy cooperation (Chen et al., 2013).

Managing BUMDes means operating village government-owned business sourced from people's money. In its development, the study of state-owned business has a complex development. This is related to the ownership status of developing company which is not only owned by the government, but also private party. Therefore, government-owned business in some experts' opinion tends to have hybrid organization character since the business owner consists of government and private elements (Bruton, Peng, Ahlstrom, Stan, \& Xu, 2015; Diefenbach \& Sillince, 2011; Inoue, Lazzarini, \& Musacchio, 2013). Consequently, the accountability design also develops, which is initially under supervision of only the government, and currently changes because of stakeholders's demand so that it will have the capacity in supervising BUMDes management accountability as explained in the following research results.

\section{Village Government's And Village Institution's Capacity}

Village government and institution play important role in the accountability of village business management. Village government is the main capital provider, thus any village business performance must be accounted for village government. The research results show that the capacity of village government is classified high, as 
concluded from the survey data of BUMDes managers' response with regard to village government's involvement in BUMDes management accountability below.

Table 2: Village Government's Capacity

\begin{tabular}{|c|c|c|c|c|}
\hline No & Indicator & $\begin{array}{l}\text { Answer } \\
\text { Choice }\end{array}$ & \multicolumn{2}{|c|}{$\begin{array}{c}\text { Frequency } \\
(\%)\end{array}$} \\
\hline \multirow[t]{4}{*}{1.} & \multirow{4}{*}{$\begin{array}{l}\text { Village } \\
\text { Government's } \\
\text { access to BUMDes } \\
\text { performance report }\end{array}$} & N/A & 0 & $0 \%$ \\
\hline & & Low & 1 & $2.4 \%$ \\
\hline & & Medium & 24 & $58.5 \%$ \\
\hline & & High & 16 & $39 \%$ \\
\hline \multirow[t]{4}{*}{2.} & \multirow{4}{*}{$\begin{array}{l}\text { Village Government } \\
\text { involvement } \\
\text { BUMDes supervisior }\end{array}$} & $\begin{array}{l}\text { Not } \\
\text { Involved }\end{array}$ & 0 & $0 \%$ \\
\hline & & $\begin{array}{l}\text { Less } \\
\text { Involved }\end{array}$ & 0 & $0 \%$ \\
\hline & & Involved & 21 & $51.2 \%$ \\
\hline & & $\begin{array}{l}\text { Highly } \\
\text { Involved }\end{array}$ & 20 & $48.8 \%$ \\
\hline \multirow[t]{4}{*}{3.} & \multirow{4}{*}{$\begin{array}{l}\text { Village } \\
\text { Government's } \\
\text { involvement } \\
\text { BUMDES } \\
\text { accountability } \\
\text { mechanism }\end{array}$} & N/A & 0 & $0 \%$ \\
\hline & & $\begin{array}{l}\text { Occasio } \\
\text { nally }\end{array}$ & 1 & $2.4 \%$ \\
\hline & & Frequent & 21 & $51.2 \%$ \\
\hline & & Routine & 19 & $46.3 \%$ \\
\hline
\end{tabular}

Source: processed primary data, 2018

According to the data above, the capacity of village government in village business management accountability is high, as marked with: (1) village government's access to BUMDes reporting; (2) village government's involvement in BUMDes supervision; and (3) village government's involvement in BUMDes accountability mechanism. Most of the respondents answer that village government has good access to BUMDes report. Moreover, some units of BUMDes have their performance report is arranged by village apparatus. In addition, although no standard mechanism is regulating the flow of BUMDes management accountability, but most of BUMDes managers answer that village government is in the mechanism or BUMDes management accountability flow. The qualitative data also show that village government is highly involved in village business management accountability. One of BUMDes directors explains in an interview that BUMDes managing lines have made the accountability report to the village government, since village government holds the majority share of village business. Besides from the perspective of village government capacity, village institution also plays important role in
BUMDes management accountability. Village institution is people's representative assigned to supervise village business operation. Therefore, this research also examines to what extent the capacity of village institution in BUMDes management accountability system is, which may be viewed in the following table.

Table 3: Village Institution's capacity

\begin{tabular}{|c|c|c|c|c|}
\hline $\mathrm{N}$ & Indicator & Answer & \multicolumn{2}{|c|}{ Frequency (\%) } \\
\hline \multirow[t]{4}{*}{1} & \multirow{4}{*}{$\begin{array}{l}\text { Village intitution's } \\
\text { access to BUMDes } \\
\text { performance report }\end{array}$} & N/A & 12 & $29.3 \%$ \\
\hline & & Low & 19 & $46.3 \%$ \\
\hline & & Medium & 7 & $17.1 \%$ \\
\hline & & High & 3 & $7.3 \%$ \\
\hline \multirow[t]{4}{*}{2} & \multirow{4}{*}{$\begin{array}{l}\text { Village institution's } \\
\text { involvement in } \\
\text { BUMDes } \\
\text { management } \\
\text { supervision }\end{array}$} & N/A & 16 & $31.7 \%$ \\
\hline & & Low & 10 & $43.9 \%$ \\
\hline & & Medium & 12 & $17.1 \%$ \\
\hline & & High & 3 & $7.3 \%$ \\
\hline \multirow[t]{4}{*}{3} & \multirow{4}{*}{$\begin{array}{l}\text { Village institution's } \\
\text { involvement in } \\
\text { BUMDes } \\
\text { accountability } \\
\text { mechanism }\end{array}$} & N/A & 0 & 0 \\
\hline & & Low & 25 & $60.9 \%$ \\
\hline & & Medium & 14 & $34.1 \%$ \\
\hline & & High & 2 & $5 \%$ \\
\hline
\end{tabular}

Source: processed primary data, 2018.

Based on table 3, the capacity of village institution in village business management accountability is not as big as the capacity of village government, as shown with village institution's low involvement in reporting mechanism. This means that village intitution is not given access right to BUMDes management accountability report. Moreover, BUMDes managers acknowledge that they do not have any formal mechanism to involve village institution in BUMDes accountability system. Similarly, village institution's involvement in village business supervision is also still low. Village business management is eventually still dominated by village government's involvement. This is justified by an informant who is an element of BUMDes Manager of Pancasan Village, Ajibarang Subdistrict, explaining that BUMDes as a village business is after all an integral part of village administration management in general. All of BUMDes activities must be known and approved by village government, especially village head. Interviews with village institution element show that their involvement in ensuring BUMDes management accountability is still low. Village government part has actually attempted to mediate village institution 
involvement in BUMDes management. Some units of BUMDes have developed cooperation and coordination with village intitutions, as acknowledged by informants that cooperation between BUMDes and village intitution has been made several times, such as in determining BUMDes activity program and socialization of the existence of village business unit.

Based on the research results, it is found that public governance in Indonesia in the context of village business management accountability does not have even capacity. Most stakeholders' public governance capacity is still of low level. Only village government has big capacity in village business management accountability. Village government is the only institution given with big access by the managers to receiving BUMDes performance report, while other stakeholders like village institution, local government, private sector, and villagers still have limited access. This means that BUMDes management accountability is still of vertical pattern, while horizontal accountability cannot be conducted yet. However, accountability does not only focus on financial and performance matters, but also involve democratic and political aspects (Schillemans, 2010, 2011). That is why the concept of horizontal accountability is an absolute requirement for public matters implementation.

That vertical accountability is strong cannot be separated from the history of BUMDes management pattern which is monopolized by village government. Based on observation results, it is found that most of village business still highly relies on village head to be the decision maker, while regulations of village business management state that village apparatuses must be of nonformal manager (director and staff). Village head holds the central position in decision making process. Government's dominance in economic activities indeed plays an important role in economic development process (Lam, 2016). Many governments in developing countries take important role in managing their economy. The government's involvement option in economy evidently affects cooperation performance. However, it is to consider that government's too far involvement may also trigger conflict of relationship between government and private sector. Therefore, avoiding problems arising from such relationship requires well-planned strategy and breakthrough. This shows how important business improvement is made at local level (Morçöl \& Wolf, 2010).

The facts of the research results show that village government capacity in village business management accountability in Indonesia is proven to be very strong. We may state that the main actor in village business is village government as represented by village head and village business managers as represented by director or leader of company. Only village government has access to BUMDes performance report. Meanwhile, village institution as villagers' representative does not have good access. However, that village business uses people's fund, it should not be accounted for only to the government, but also to the people directly. A theory of public budget explains that public sector budget manager should not only prioritize relationship with the state, but relationship with citizens is the most important matter (Hwang et al., 2013; Murphy \& Skillen, 2018).

Based on the research results, it is also found that the reason of village government's dominance in BUMDes management is village head's distrust in BUMDes managers. This fact shows village government's central role and dominance in BUMDes management process. Village head and officials play double roles of village officials and BUMDes managers at the same time. This makes BUMDes management unprofessional. BUMDes operational activities still merge with village administrative operation, and even BUMDes shares the same location with village office. It is difficult to distinguish BUMDes's property from village's property. The people find it difficult to assess to what extent BUMDes contributes to village. There is no socialization of profit sharing rule to the people, thus they do not know how much of BUMDes's profit is included into Village Own-Source Revenue (PADes).

Continuous learning and partnership in organization is an important way to make a change in an organization which is part of the process towards modern organization (Malizia, 2016; Rhodes \& Price, 2011). The "Post-Bureaucratic Paradigm" characteristic is modern organization's characteristic which may be viewed from the perspective of 
policy, management culture, structure and orientation to marketing (Malizia, 2016; Rhodes \& Price, 2011). In this case, villagers should learn how to run an organization in a "modern" way. However, village will face tougher challenge in the future, thus they should be equipped with sufficient skills. Therefore, BUMDes management should be directed to optimization of stakeholders' capacity through public governance approach. Based on this, BUMDes managers' capacity and stakeholders' participation in BUMDes management need to be confirmed and reinforced to loosen the concentration of village government dominance, thus business-government relation will be wellbalanced. Local government is required to open up to all parties. An open government is an important innovation to encourage trustworthy and inclusive administration (Grimmelikhuijsen \& Feeney, 2017).

\section{Local Government's (Sub-district) Capacity}

Although village has autonomy in administration operation, but village financial source cannot be separated from local government. Therefore, the utilization of village fund for village business should be accounted for to local government. The concerned accountability mechanism is in the context of village fund utilization, as the form of accountability of public fund utilization. Local government should be given with capacity and must be part of the accountability mechanism of village business management. The research results show that public governance capacity from the perspective of local government capacity in village business management accountability is classified as low. Village governments have actually submitted the report indirectly with regard to village fund utilization for BUMDes activities. The report is expressed in the accountability report of village fund utilization. In particular, BUMDes management reporting to subdistrict has not been made yet. Village government only informs of BUMDes development in general to subdistrict, thus local government only learns about general information of BUMDes activities implementation. Below is an explanation of the research results of the capacity of local government, in this case subdistrict, with indicators: (1) Low involvement in BUMDes supervision; (2) Local government's lack of access to BUMDes performance report; and (3) Local government's lack of involvement BUMDes management accountability mechanism. These data are obtained from the survey conducted with BUMDes managers.

Table 4: Local Government's Capacity

\begin{tabular}{|c|c|c|c|c|}
\hline No. & Indicator & Answer & \multicolumn{2}{|c|}{ Frequency $(\%)$} \\
\hline \multirow[t]{4}{*}{1.} & \multirow{4}{*}{$\begin{array}{l}\text { Involvemen } \\
\mathrm{t} \text { in } \\
\text { BUMDes } \\
\text { managemen } \\
\mathrm{t} \\
\text { supervision }\end{array}$} & N/A & 34 & $82.9 \%$ \\
\hline & & Low & 2 & $4.9 \%$ \\
\hline & & Medium & 5 & $12.2 \%$ \\
\hline & & High & 0 & $0 \%$ \\
\hline \multirow[t]{4}{*}{2.} & \multirow{4}{*}{$\begin{array}{l}\text { Local } \\
\text { government } \\
\text { 's access to } \\
\text { BUMDes } \\
\text { performanc } \\
\text { e report }\end{array}$} & N/A & 36 & $87.8 \%$ \\
\hline & & Low & 3 & $7.3 \%$ \\
\hline & & Medium & 2 & $4.9 \%$ \\
\hline & & High & 0 & $0 \%$ \\
\hline \multirow[t]{4}{*}{3.} & \multirow{4}{*}{$\begin{array}{l}\text { Involvemen } \\
\mathrm{t} \text { in } \\
\text { accountabili } \\
\text { ty } \\
\text { mechanism }\end{array}$} & N/A & 36 & $87.8 \%$ \\
\hline & & Low & 5 & $12.2 \%$ \\
\hline & & Medium & 0 & $0 \%$ \\
\hline & & High & 0 & $0 \%$ \\
\hline
\end{tabular}

Source: processed primary data, 2018.

Based on table 4 , it is found that local government's capacity in the management and management accountability of village business is low. By regulation, local government does not have the institutional capacity to directly engage in village business management, since village business management is completely village government's responsibility. Basically, the existence of BUMDes is part of the central government's effort to decentralize village financial management to villagers. Village is given with fiscal space to manage its potential creatively and innovatively. BUMDes development is the representation of privatization model application in public sector organization. The basic principle of privatization is to reduce government's involvement in public sector organization (Vickers \& Yarrow, 2012). Government only takes the role only to give guidance without getting involved in operational activities. This is intended to have public service conducted professionally, fairly and accountably.

Public governance capacity based on subdistrict role indicator is classified low, as viewed with subdistrict government's low 
access to BUMDes performance report, its low involvement in accountability mechanism, and its lack of involvement in supervision. BUMDes manager part perceives that BUMDes management accountability should only be made to village government and villagers. Therefore, local governments, particularly subdistrict, tend not to be given with capacity in BUMDes management accountability mechanism.

\section{Private Sector's Capacity}

Private sector is an important pillar in the concept of governance. Private sector's involvement is proven to improve the performance of public sector management. Village business management, even if it uses village-owned fund, should give the opportunity for private sector involvement. Therefore, private sector's capacity is also an important part in village business management accountability. The research results show that village business managers have not given opportunity to private sector to engage in village business management accountability, as shown with private sector's lack of access to village business management accountability report. On the other hand, private sector is well involved both in terms of cooperation and capitalization. Manager part acknowledges that they have not made any mechanism to give private part with good access to the management report of village business which involves private sector. The most apparent indicator to show private sector's low capacity in village business management accountability is that there is no good access to village business management accountability report. The survey data related to private sector's capacity in village business management is explained in the following table.

Table 5: Private Sector's Capacity

\begin{tabular}{|c|c|c|c|c|}
\hline \multirow{2}{*}{$\begin{array}{l}\text { No. } \\
1 .\end{array}$} & Indicator & \multirow{2}{*}{$\begin{array}{l}\begin{array}{c}\text { Answer } \\
\text { Choice }\end{array} \\
\text { N/A }\end{array}$} & \multicolumn{2}{|c|}{ Frequency (\%) } \\
\hline & \multirow{4}{*}{$\begin{array}{l}\text { Cooperation with } \\
\text { private sector in } \\
\text { village business } \\
\text { management }\end{array}$} & & 4 & $9.8 \%$ \\
\hline \multirow{3}{*}{1.} & & Low & 14 & $34.1 \%$ \\
\hline & & Medium & 20 & $48.8 \%$ \\
\hline & & High & 3 & $7.3 \%$ \\
\hline \multirow[t]{4}{*}{2.} & \multirow{4}{*}{$\begin{array}{lr}\text { Private } & \text { sector's } \\
\text { access to village } \\
\text { business management } \\
\text { report }\end{array}$} & N/A & 14 & $34.1 \%$ \\
\hline & & Low & 19 & $46.3 \%$ \\
\hline & & Medium & 4 & $9.8 \%$ \\
\hline & & High & 4 & $9.8 \%$ \\
\hline 3. & sector's & N/A & 20 & $48.8 \%$ \\
\hline
\end{tabular}

\begin{tabular}{l|l|l|l|l} 
capital support in & Low & 17 & $41.5 \%$ \\
\cline { 3 - 5 } village business & Medium & 2 & $4.9 \%$ \\
\cline { 3 - 5 } & management & High & 2 & $4.9 \%$ \\
\hline
\end{tabular}

Source: processed primary data, 2018.

Based on data table 5, private sector's capacity in business management is actually relatively high, as shown with the survey that 20 units of village business acknowledge that they cooperate with and are supported by private sector with capitalization. However, of some of the units, only $9.8 \%$ have given private sector with access to their business management accountability report. Meanwhile, some other respondents answer that they have no cooperation with and are not supported with fund by private sector. Consequently, it is reasonable that most of village business units do not have any mechanism to involve private sector in their village business management accountability. This is expressed by $\mathbf{M}$ who is a government element of Batuanten Village, Cilongok Subdistrict, that their village business has not cooperated with any private sector. Instead, they expect that local government will facilitate cooperation between village business unit and private sector, particularly in relation to capitalization.

Private sector's public governance capacity still needs to be improved in order to increase BUMDes business scale. Current world development requires private sector's involvement more widely in the development of an area, particularly village. There is a strong wave to encourage private sector to engage more in rural development (Woodward \& Safavi, 2015). Besides, the partnership between public sector and private sector also important (Bjärstig \& Sandström, 2017). Such a partnership has been a popular instrument to regulate rural development. Public sector and private sector partnership is a significant solution to improve the effectiveness and legitimacy of sustainable rural governance in terms of participation and accountability. Private company's involvement is important to improve an inclusive growth prospect, and to create and improve new production potential, particularly in village (Zulkhibri, 2018). To accelerate economic development, the development of entrepreneurial spirit needs to be encouraged, particularly for village. Entrepreneurial value transformation requires synergy between government policy to 
regulate business environment and entrepreneur to operate therein (Najmaei \& Sadeghinejad, 2016). Through entrepreneurial values application, BUMDes managers will be more freely implement corporate actions without village government's preference to hold them back. Entrepreneurial values application may ensure higher social prosperity for people at large (Fanti \& Buccella, 2017). Therefore, the relation mechanism in BUMDes management in the future needs to be directed towards optimization of BUMDes managers' role through entrepreneurial spirit full application.

\section{Villagers' Capacity}

In the concept of governance, people are not an object, but a subject that should be actively involved. To maximize people's role, organization should open access for people as widely as possible. People's bargaining position must be equal to that of other stakeholders. Therefore, this research measures villagers' capacity in village business management accountability process. The research results show that public governance capacity from the perspective of villagers' capacity is classified low, as shown with the following indicators: (1) villagers do not have good access to village business management accountability report; (2) villagers' involvement in village business management accountability forum is still low; (3) villagers' involvement in village business management supervision is still low. These data are obtained from the survey with BUMDes managers as follows.

Table 6: Villagers' Capacity

\begin{tabular}{|c|c|c|c|c|}
\hline No. & Indicator & Answer & \multicolumn{2}{|c|}{ Frequency $(\%)$} \\
\hline \multirow[t]{4}{*}{1.} & \multirow{4}{*}{$\begin{array}{l}\text { Villagers' access to } \\
\text { BUMDes performance } \\
\text { report }\end{array}$} & N/A & 0 & $0 \%$ \\
\hline & & Low & 27 & $65.9 \%$ \\
\hline & & Medium & 9 & $22 \%$ \\
\hline & & High & 5 & $12.2 \%$ \\
\hline \multirow[t]{4}{*}{2.} & \multirow{4}{*}{$\begin{array}{l}\text { Villagers' involvement } \\
\text { in } \quad \text { BUMDes } \\
\text { accountability } \\
\text { mechanism }\end{array}$} & N/A & 0 & $0 \%$ \\
\hline & & Low & 13 & $31.7 \%$ \\
\hline & & Medium & 25 & $61.0 \%$ \\
\hline & & High & 3 & $7.3 \%$ \\
\hline \multirow[t]{4}{*}{3.} & \multirow{4}{*}{$\begin{array}{lr}\text { People's } & \text { involvement } \\
\text { in } & \text { BUMDes } \\
\text { supervision } & \end{array}$} & N/A & 0 & $0 \%$ \\
\hline & & Low & 27 & $65.9 \%$ \\
\hline & & Medium & 13 & $31.7 \%$ \\
\hline & & High & 1 & $2.4 \%$ \\
\hline
\end{tabular}

Source: processed primary data, 2018.
Based on table 6, it is found that, generally, villagers' capacity is not optimal yet, since most of managers have not provided any formal accountability mechanism to involve people at large. Village business management accountability forum is held only through village deliberation initiated by village institution. Village deliberation forum is commonly attended only by village government, village institution, and public figure as people's representative. Therefore, horizontal accountability has not been optimally made by village business managers with villagers at large. This is also acknowledged by manager part that has not found any appropriate way for villagers to have good access to village business management accountability report. Villagers' involvement is only in the form of informal forums. People's involvement and delivery of information related to BUMDes management reporting to villagers are also presented in people informal forums.

Village government element dominance is still high, causing limited and obstructed action of BUMDes corporation in collecting village's full potential. This shows that there is behavior inappropriate to business conduct, which is democratic business conduct which symbolizes a condition where people hold corporation to account for their actions. This ethic transfers power from organized capital and wealth center (in this case APBDes) and return them to a democratic place democratically together with the people (Rhodes, 2016). The voluntarism principle remains existing and necessary in managing a social business (Dentchev, Haezendonck, \& van Balen, 2017), since such a social business activity cannot be separated from local people's life (Moingeon, Yunus, Moingeon, \& Lehmann-ortega, 2015; Villis, Strack, Bruysten, \& Yunus, 2013; Yunus, Moingeon, \& Lehmann-Ortega, 2010). In addition, government's intervention mechanism in social business should be clear. Therefore, the higher village's responsibility in managing village fund, more changes are required in its management.

\section{Public Governance in the Accountability of BUMDes} Management

Public governance is defined as the interaction of various actors in BUMDes 
management accountability process. People may participate in supervision in controlling BUMDes management process. This is conducted so that BUMDes management may be accounted for both vertically and horizontally. The more extensive the definition of public, the higher the people's opportunity to be involved as BUMDes supervisory agent is. On the other hand, BUMDes managers and village government should open up to this public involvement. It will be meaningless that when people respond, but such response is ignored by BUMDes managers. Synergy between people, government and other stakeholders in building trustworthy accountability system needs to be developed, so that proses public accountability will operate effectively.

The accountability mechanism in BUMDes management needs to be directed towards optimization of stakeholders' capacity through public governance approach which allows any concerned groups to engage in public policy formulation and implementation (Bannink \& Ossewaarde, 2012; Guo, 2017). Through this approach, public accountability is expected to aim more for all stakeholders' involvement in villagers' property management. Village government's role in management accountability system should be confirmed as a shareholder, so that BUMDes management accountability report must be submitted to village government. Villagers' role must also be facilitated as the right holder of village fund used by BUMDes, thus villagers must also be given with access to the development of BUMDes management. Similarly, other parts contributing to the development of BUMDes management must also be given with good access to the development of BUMDes management.

\section{Conclusion}

Public governance capacity in BUMDes management accountability is proven to be low, since public involvement opportunity is not even created yet. The most dominant part in the implementation of BUMDes management accountability system is village government, while other actors have not had sufficient capacity. Therefore, the accountability mechanism in BUMDes management should be directed towards strengthening of public governance capacity.
Public governance capacity may be strengthened by opening the opportunity for stakeholders' involvement in BUMDes management accountability mechanism. Every part should be given with clear role so that they will understand their responsibility. Public governance capacity strengthening based public accountability system will influence the implementation of democratic public accountability. But we must remember that village communities have unique characteristics where not all systems can operate without local wisdom.Therefore, public governance capacity improvement is absolutely required in BUMDes management accountability system with local wisdom.

\section{Acknowlegments}

This research was supported by DRPM of the Ministry of Research Technology and Higher Education (Kemristekdikti) Republic Indonesia as well as the LPPM Jenderal Sudirman University which has facilitated this research. Not to forget the author also expressed his gratitude to the respondents and informants in this case the managers of BUMDes, village officials, village community leaders, and village communities.

\section{References}

Bannink, D., \& Ossewaarde, R. (2012). Decentralization: New Modes of Governance and Administrative Responsibility. Administration and Society, 44(5), 595-624. https://doi.org/10.1177/0095399711419 096

Benijts, T. (2014). A Business Sustainability Model for Government Corporations. A Belgian Case Study. Business Strategy and the Environment. https://doi.org/10.1002/bse.1784

Bjärstig, T., \& Sandström, C. (2017). Publicprivate partnerships in a Swedish rural context - A policy tool for the authorities to achieve sustainable rural development? Journal of Rural Studies. https://doi.org/10.1016/j.jrurstud.2016. 11.009

Bruton, G. D., Peng, M. W., Ahlstrom, D., 
Stan, C., \& Xu, K. (2015). State-owned Enterprises Around the WORLD as Hybrid Organizations. Academy of Management Perspectives. https://doi.org/10.5465/amp.2013.0069

Chen, W., Woods, A., \& Singh, S. (2013). Organisational change and development of reformed Chinese township and village enterprises. Journal of Organizational Change Management. https://doi.org/10.1108/0953481131132 8399

Creswell, J. W. (2013). Qualitative Inquiry \& Research Design: Choosing Among Five Approaches. In Sage Publications. https://doi.org/10.1111/14679299.00177

Dentchev, N. A., Haezendonck, E., \& van Balen, M. (2017). The Role of Governments in the Business and Society Debate. Business and Society. https://doi.org/10.1177/0007650315586 179

Diefenbach, T., \& Sillince, J. A. A. (2011). Formal and informal hierarchy in different types of organization. Organization Studies. https://doi.org/10.1177/0170840611421 254

Dubnick, M. J. (2017). Accountability and ethics: reconsidering the relationships. International Journal of Organization Theory \& Behavior. https://doi.org/10.1108/ijotb-06-032003-b002

Eversole, R., Barraket, J., \& Luke, B. (2014). Social enterprises in rural community development. Community Development Journal. https://doi.org/10.1093/cdj/bst030

Fanti, L., \& Buccella, D. (2017). Privatisation or State Ownership When Labour Market is Unionised? Folia Oeconomica Stetinensia. https://doi.org/10.1515/foli-2016-0002

Geurtsen, A., Sprenger, P. J. M., \& Schoormans, L. (2010). A conceptual accountability model for the social enterprise. EGPA conference, (September), 1-21.

Grimmelikhuijsen, S. G., \& Feeney, M. K.
(2017). Developing and Testing an Integrative Framework for Open Government Adoption in Local Governments. Public Administration Review. https://doi.org/10.1111/puar.12689

Guo, B. (2017). China's Administrative Governance Reform in the Era of "New Normal." Journal of Chinese Political Science, 22(3), 357-373. https://doi.org/10.1007/s11366-0179483-x

Hudaya, M., Smark, C., Watts, T., \& Silaen, P. (2015). The Use of Accountability Reports and the Accountability Forum: Evidence from an Indonesian Local Government. Australasian Accounting, Business and Finance Journal, 9(4), 57-70. https://doi.org/10.14453/aabfj.v9i4.5

Hwang, K., Jensen, L. S., Hult, K. M., Roberts, P. S., \& Dull, M. M. (2013). The Impact of Accountability and Accountability Management on Performance at the Street Level. Public Administration and Public Affairs Laura.

Inoue, C. F. K. V., Lazzarini, S. G., \& Musacchio, A. (2013). Leviathan as a minority shareholder: Firm-level implications of state equity purchases. Academy of Management Journal. https://doi.org/10.5465/amj.2012.0406

Lam, N. M. K. (2016). Business-government relationship in economic development. Asian Education and Development Studies. https://doi.org/10.1108/AEDS08-2016-0067

Leroux, K. (2015). Paternalistic or Participatory Governance? Examining Opportunities Social for Client Participation in Nonprofit. Public Administration Review, 69(3), 504517.

Löffler, E., Parrado, S., Bovaird, T., Van Ryzin, G., Loeffler, E., Downe, J., ... Rees et al, 2012. (2012). Emerging trends in public management and governance. International Review of Administrative Sciences. https://doi.org/10.1111/j.15406210.2007.00773.x 
Malizia, P. (2016). Sailing: Organizational Change: Forms and Hibrydisms of Post-bureaucratic Organizations. The International Journal of Knowledge, Culture, and Change Management: Annual Review, 11(1), 93-104. https://doi.org/10.18848/14479524/cgp/v11i01/50085

Moingeon, B., Yunus, M., Moingeon, B., \& Lehmann-ortega, L. (2015). Building Social Business Models : Lessons from the Grameen Experience Building Social Business Models : Lessons from the Grameen Experience. Long Range Planning, 43(2-3), 308-325. https://doi.org/10.1016/j.lrp.2009.12.00 5

Morçöl, G., \& Wolf, J. F. (2010). Understanding Business Improvement Districts: A New Governance Framework. Public Administration Review. https://doi.org/10.1111/j.15406210.2010.02222.x

Murphy, M., \& Skillen, P. (2018). Exposure to the Law: Accountability and Its Impact on Street-level Bureaucracy. Social Policy and Society, 17(1), 3546.

https://doi.org/10.1017/s147474641600 0506

Najmaei, A., \& Sadeghinejad, Z. (2016). Toward a theory of business models and business modeling in public entrepreneurship. Contemporary Issues in Entrepreneurship Research. https://doi.org/10.1108/S2040724620160000006004

Petrovsky, N., James, O., \& Boyne, G. A. (2015). New leaders' managerial background and the performance of public organizations: The theory of publicness fit. Journal of Public Administration Research and Theory, 25(1), 217-236. https://doi.org/10.1093/jopart/muu008

Rhodes, C. (2016). Democratic Business Ethics: Volkswagen's Emissions Scandal and the Disruption of Corporate Sovereignty. Organization Studies. https://doi.org/10.1177/0170840616641 984

Rhodes, C., \& Price, O. M. (2011). The post78 bureaucratic parasite: Contrasting narratives of organizational change in local government. Management Learning, 42(3), 241-260. https://doi.org/10.1177/1350507610385 765

Ringeling, A. (2015). How public is public administration? A constitutional approach of publicness. Teaching Public Administration, 33(3), 292-312. https://doi.org/10.1177/0144739415573 268

Schillemans, T. (2010). Redundant Accountability: The joint impact of horizontal and vertical accountability on autonomous agencies. Public Administration Quarterly.

Schillemans, T. (2011). Does horizontal accountability work? Evaluating potential remedies for the accountability deficit of agencies. Administration and Society, 43(4), 387-416. https://doi.org/10.1177/0095399711412 931

Setyoko, P. (2011). Akuntabilitas Administrasi Keuangan Program Alokasi Dana Desa (ADD). Jurnal Ilmu Administrasi Negara.

Smith, S. R. (2010). Hybridization and nonprofit organizations: The governance challenge. Policy and Society. https://doi.org/10.1016/j.polsoc.2010.0 6.003

Valentinov, V. L. (2011). Accountability and the Public Interest in the Nonprofit Sector: A Conceptual Framework. In SSRN. https://doi.org/10.1111/j.14680408.2010.00514.x

Vickers, J., \& Yarrow, G. (2012). Economic Perspectives on Privatization. Journal of Economic Perspectives. https://doi.org/10.1257/jep.5.2.111

Villis, U., Strack, R., Bruysten, S., \& Yunus, M. (2013). The Power of Social Business: Lessons from Corporate Engagements with Grameen. Boston Consulting Group.

Wang, S., \& Yang, Y. (2010). Grassroots democracy and local governance: Evidence from rural China. Procedia - 
Social and Behavioral Sciences. https://doi.org/10.1016/j.sbspro.2010.0 5.069

Warner, M. E. (2010). The future of local government: Twenty-first-century challenges. Public Administration Review. https://doi.org/10.1111/j.15406210.2010.02257.x

Woodward, R., \& Safavi, M. (2015). Private sector development. In Economic and Social Development of the Southern and Eastern Mediterranean Countries. https://doi.org/10.1007/978-3-31911122-3_5

Xia, M. (2011). Social Capital and Rural Grassroots Governance in China. Journal of Current Chinese Affairs, 2, 135-163.

Yunus, M., Moingeon, B., \& LehmannOrtega, L. (2010). Building social business models: Lessons from the grameen experience. Long Range Planning. https://doi.org/10.1016/j.lrp.2009.12.00 5

Zulkhibri, M. (2018). Rethinking the Catalytic Role of Private Sector for Inclusive Growth. Journal of Development Policy and Practice. https://doi.org/10.1177/2455133317737 937

\section{Biographies}

Denok Kurniasih, was born in Cilacap, May 1, 1979. He completed his doctoral program in Public Administration at Padjadjaran University Bandung in 2013. He currently researches a lot about collaborative governance, public management, public organizations, and studies on village government management, particularly related to public finance and management of VillageOwned Enterprises (BUMDes). The author is a lecturer in the Public Administration Program, FISIP, Jenderal Sudirman University Purwokerto.

Paulus Israwan Setyoko, was born in Yogyakarta, December 23, 1959. He is a professor in the field of Public Policy who actively examines public policy issues. Has written in various national and international journals, actively guides theses and dissertations, and is a guest lecturer (visiting professor) in various universities. Currently registered as a lecturer in the Magister of Public Administration Program, FISIP, Jenderal Sudirman University Purwokerto. 